DOI: $10.2478 /$ lpts-2018-0013

APPLIED PHYSICS

\title{
ADDITIVE MANUFACTURING AND CASTING TECHNOLOGY COMPARISON: MECHANICAL PROPERTIES, PRODUCTIVITY AND COST BENCHMARK
}

\author{
A. Vevers, A. Kromanis, E. Gerins, J. Ozolins \\ Institute of Mechanical Engineering \\ Riga Technical University \\ 36a Viskalu Str., Riga, LV-1006, LATVIA \\ e-mail: artursvevers@gmail.com
}

\begin{abstract}
The casting technology is one of the oldest production technologies in the world but in the recent years metal additive manufacturing also known as metal $3 \mathrm{D}$ printing has been evolving with huge steps. Both technologies have capabilities to produce parts with internal holes and at first glance surface roughness is similar for both technologies, which means that for precise dimensions parts have to be machined in places where precise fit is necessary. Benchmark tests have been made to find out if parts which are produced with metal additive manufacturing can be used to replace parts which are produced with casting technology. Most of the comparative tests have been made with GJS-400-15 grade which is one of the most popular cast iron grades. To compare mechanical properties samples have been produced using additive manufacturing and tested for tensile strength, hardness, surface roughness and microstructure and then the results have been compared with the samples produced with casting technology. In addition, both technologies have been compared in terms of the production time and production costs to see if additive manufacturing is competitive with the casting technology. The original paper has been written in the Latvian language as part of the Master Thesis within the framework of the production technology study programme at Riga Technical University.
\end{abstract}

Keywords: additive manufacturing, casting, 3D printing, hardness, surface roughness, tensile strength

\section{INTRODUCTION}

In recent years a new technology has been evolving very fast, which is called metal Additive Manufacturing or metal 3D printing. The principle of additive manufacturing (AM) operation is that you use $3 \mathrm{D}$ object (CAD part) which is sliced into 2D sections and part is produced layer by layer from bottom to top. For metal additive manufacturing there are many technology types and names for each method. Most common ones are Selective Laser Melting (SLM) and Direct Metal Laser Sintering (DMLS). Metal additive manufacturing machine in the SLM method applies a thin 
layer of metal powder (usually 20-50 $\mu \mathrm{m}$ ) on a build platform then based on sliced 2D data generates a laser scan pattern and with CNC controlled laser melts powder only in places where the part is located. Then the next powder layer is applied and melted together with the previous layer. The process is repeated layer by layer till the part is finished. DMLS method works based on the same 3D object slicing principle but it uses a different powder supply principle. In the DMLS method powder is injected straight in a laser beam. This method works faster because it saves time for powder recoating process but parts that are produced using this method have a worse surface quality. Additive manufacturing opens new possibilities for complex part production and can change the way the parts are designed and produced in the future [1].

Casting technology is one of the oldest production technologies in the world. Due to its simplicity, the basic principles of technology have not changed for many years. Casting technology and Additive Manufacturing are completely different technologies by the principles how they work, but it is possible to find many similarities in the parts that can be produced with technologies: complex internal channels, surface roughness, and dimensional accuracy for both technologies are in very close tolerances [2].

The main disadvantage of the casting technology is start-up costs for a new project because it is time consuming and expensive to produce a new pattern. It takes many hours to redesign a 3D model with all necessary draft angles according to the split line so it can be used for pattern design which means that in reality your part will not be the same as planned in the beginning. On the other hand, additive manufacturing does not have these design limitations which means that you can start to produce parts straight from a 3D file and gain time on redesign and pattern manufacturing.

Since additive manufacturing is a new technology, which develops very rapidly, a decision has been made to compare this technology with the casting technology and the objective of the research is to determine whether it is possible to produce parts using metal additive manufacturing to replace the cast parts.

\section{MATERIALS AND METHODS}

To benchmark additive manufacturing to casting technology a decision has been made to compare tensile strength, hardness, surface roughness, microstructure and chemical composition tests for samples produced using both technologies. In addition, technologies have been compared to each other to determine production time and approximate costs. All the tests have been made with iron powder, which corresponds to GJS-400-15 material grade for castings. It is not common to use iron for additive manufacturing but as one of the authors' works in the iron casting foundry, it gives access to the data about this metal grade as well as equipment to accurately compare the samples. GJS-400-12 metal grade has been used because this ductile iron grade is one of the most widely used grades for cast iron parts. Samples have been produced on 3D systems ProX DMP 300 machine. Machine is equipped with single $500 \mathrm{w}$ laser and the build platform for this machine is $250 \times 250 \times 325 \mathrm{~mm}$. Casting samples have been produced of GJS-400-15 grade in the foundry which uses a green sand technology for moulding [2]. 
The first test has been done to compare chemical composition. Both samples have been compared using Thermo Fischer 3480 OES thermal analyser. AM iron powder by manufacturer's specification corresponds to GJS-400-15 metal grade and the results have also approved it. Chemical composition is very close to parts, which are cast with only some minor deviations. Since cast iron grades do not have specified element values (only suggested), it means that this powder can be used in parts to replace castings.

In addition, the samples have been compared for microstructure. The samples have been polished and surfaces prepared with etching. Microstructure of AM sample and that of cast sample are very similar. Both samples have shown the same ductile iron microstructure with spherical graphite nodules.

\subsection{TENSILE STRENGTH TESTS}

To compare mechanical properties for both technologies, test specimens have been made using both technologies. For AM, test specimens have been produced using the SLM technology with $30 \mu \mathrm{m}$ layer thickness. Samples using AM have been made of iron powder, which corresponds to GJS-400-15 iron grade. Samples have been made with machining allowances and machined according to ISO6892-1:2009 tensile strength standard for casting samples. Testing has been done on Hegewald \& Pesche Inspekt 250 tensile strength testing machine [3].

For GJS-400-15 grade standard, a tensile strength minimal value should be $400 \mathrm{MPa}$ and elongation should be at least $15 \%$. Average values of AM sample tests are $440 \mathrm{MPa}$ and elongation $-16.78 \%$. Testing has shown very stable results: a tensile strength value has changed $+-20 \mathrm{MPa}$ and elongation changed $+-1 \%$. It is possible to see that breaking surface for both technologies looks almost the same (Fig. 1). Tensile strength results have shown that AM can produce the same quality parts as the casting technology and can maintain necessary values for specific material grade standard. During research it has been found that there are some other experiments which have been done with other materials with also very successful results. With other materials, additive manufacturing shows even better tensile strength results compared to casting technology [4].

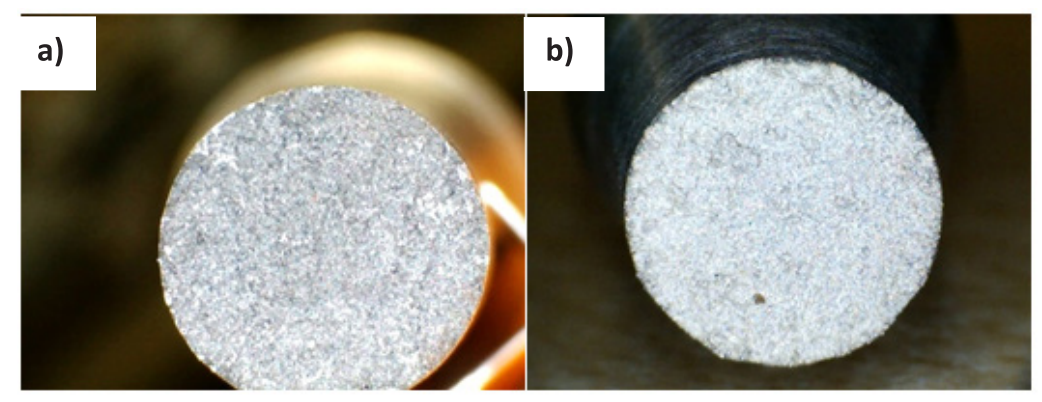

Fig. 1. Comparing breaking surface of tensile strength tests: a) AM sample, b) casting sample. 
Test for hardness has been made according to EN ISO 6506-1:2005 standard. It has shown average values between 160-175 HB. By standard for GJS-400-15, it should be in the range of 135-180 HB. The results have shown that AM part results are in the range and closer to upper values. In hardness tests it has been observed that using AM it is possible to get very close hardness values for whole part even if the wall thicknesses are different. For the casting technology it is impossible because it will show higher values for thinner sections and lower for thicker because cooling time is different. For additive manufacturing, layer thickness is relatively small compared to part size and cools down very fast and it is almost the same for all layers. Additive manufacturing in the SLM method allows for easy control and maintaining of cooling time by increasing powder recoating time between the layers, for example, when producing part with big wall thickness it is possible to increase wait time and let the part cool down more between layers [5].

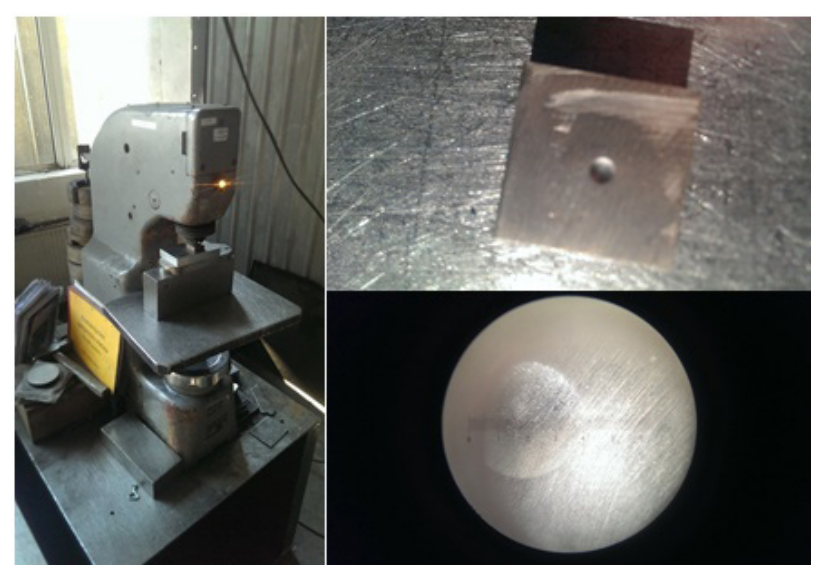

Fig. 2. Hardness measuring.

\subsection{SURFACE ROUGHNESS}

To compare surface roughness Taylor Hobson profiler has been used. AM samples and cast samples have been compared to determine if AM surface quality is equivalent to parts, which are cast in greensand. By evaluating the measured values it is possible to see that AM surface quality is better. Maximal surface waviness for AM parts is $60 \mu \mathrm{m}$ but for cast parts it is $80 \mu \mathrm{m}$. Average surface roughness calculated by ISO standard is Ra $11 \mu \mathrm{m}$ for AM parts and Ra $13.5 \mu \mathrm{m}$ for cast parts.

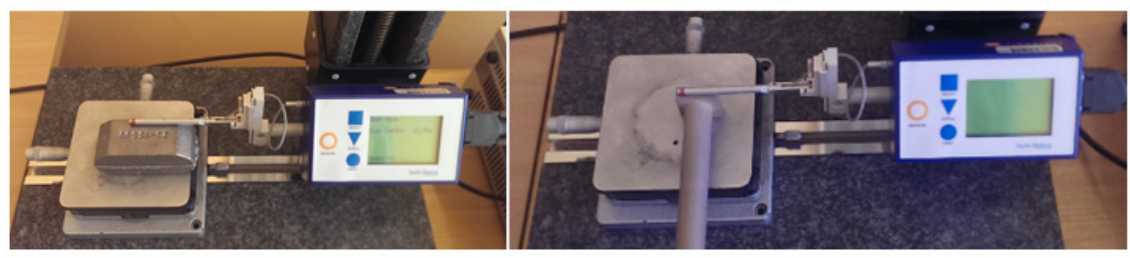

Fig.3. Surface roughness measuring process. 

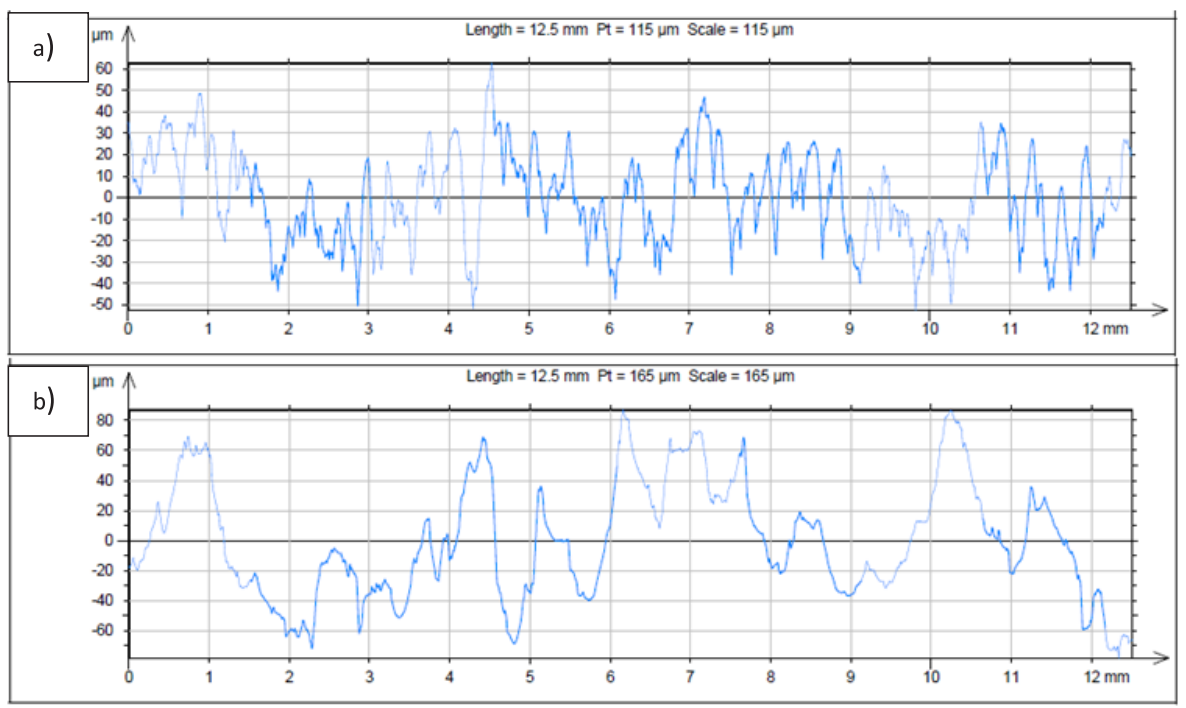

Fig. 4. Surface roughness graphics: a) graphic shows AM sample, b) graphic for casting.

\subsection{PRODUCTION TIME}

To compare production time it is not possible to make a small sample and then compare with the casting technology by volume or weight. Decision is to compare both technologies on one part, which is typical geometry for the casting industry. It weights around $1 \mathrm{~kg}$ and to make such kind of part it would be necessary to use 2 cores to make this part using the casting technology. Production time and costs have been compared for 1 and for 10 parts by values obtained by choosing each technology and buying the outsourcing service.

Part, which has been used for comparison purposes, is of average complexity for the casting technology. To cast such kind of part, it would be necessary to use 2 cores, which means two additional core boxes for pattern equipment. Production time has been calculated from time when company receives 3D CAD geometry from a customer. For casting technology it would be necessary to have around 3 days to redesign a 3D model with all necessary draft angles and prepare 3D pattern geometries. Then it would be necessary to have around 2 weeks from 3D geometries to a ready pattern - this includes $\mathrm{CNC}$ machining for negatives, $\mathrm{CNC}$ machining for core boxes and copying epoxy models and making the gating system. When pattern equipment is finished it would take additional time for core production and forming. For the casting technology an additional benefit is that usually in one mould there is more than 1 part and in one casting process it is possible to produce 10 parts. Next step would be the moulding and casting process, which takes around half an hour. When the casting process is finished the mould should cool down around 4 hours. In the end, when the mould is cooled down, parts can be taken out for post processing grinding, shot blasting etc.

All these steps are not needed in the AM process. It would be necessary to have around $2-4$ hours to prepare a program in slicer to start producing the part. 
For AM most time is spent on the printing process. With $30 \mu \mathrm{m}$ layer thickness, for this part one layer printing time is around $0.5-1 \mathrm{~min}$. The total printing time for this part would be 72 hours. After printing usually parts have to go through the heat treatment process for stress relief. It takes additional 2 hours. The last step for AM is post-processing where parts are cut of the build plate, separated of support structures and polished.

In Table 1, it is possible to see typical values or both production technologies for 1 and for 10 parts side by side. There are steps which are only for AM or the casting technology and there are steps which are common to both technologies. It is clearly visible that AM has advantages during the first steps. If it is necessary to produce only $1-4$ parts it will be more convenient to use the AM technology, but for series production for this part the casting technology is more suitable. At the moment, AM is suitable for products which are not possible to produce with other technologies or in the cases where time is a limiting factor, for example, production companies, that have equipment, which has broken down, cannot afford to stop production but spare part delivery takes too much time.

Table 1

Production Time Comparison for Both Technologies for 1 and 10 Parts

\begin{tabular}{|l|c|c|c|c|}
\hline & \multicolumn{2}{|c|}{1 part } & \multicolumn{2}{c|}{10 parts } \\
\hline Task & $\begin{array}{c}\text { Production } \\
\text { time for AM } \\
\text { (h) }\end{array}$ & $\begin{array}{c}\text { Production } \\
\text { time for } \\
\text { casting }(\mathrm{h})\end{array}$ & $\begin{array}{c}\text { Production } \\
\text { time for AM } \\
(\mathrm{h})\end{array}$ & $\begin{array}{c}\text { Production time } \\
\text { for casting }(\mathrm{h})\end{array}$ \\
\hline CAD modelling & 0 & 24 & 0 & 24 \\
\hline Pattern equipment production & 0 & 310 & 0 & 315 \\
\hline Core production & 0 & 1 & 0 & 1 \\
\hline Setup forming & 0 & 0.5 & 0 & 0.5 \\
\hline Preparing program for AM & 2 & 0 & 2 & 0 \\
\hline Casting, Cooling time & 0 & 8 & 0 & 8 \\
\hline AM process & 72 & & 960 & 20 \\
\hline Post-processing & 4 & 2 & 22 & 346 \\
\hline Total & 82 & 351 & 982 & \\
\hline
\end{tabular}

\section{COSTS}

To compare costs, the same comparison principle has been used as for production time. The same part has been used, and costs have been compared for 1 and 10 parts. 3D geometry has been sent to a few casting companies and a few companies that provide the AM service. Average price received from casting companies is 4000 EUR for pattern equipment and 14.50 EUR - for each part. For the casting technology, there are high start-up costs because it is necessary to cover pattern equipment costs. For one and also for ten parts, the price is very high because the casting technology is suitable for series production. In case if it is necessary to produce 5000 parts then the pattern cost is divided and one part costs only 15.30 EUR. 
On the other hand, the AM technology does not have start-up costs, but printing time is very slow. Price for 1 part, which is produced with additive manufacturing, is 3650 EUR and the price is almost the same for producing 1 part or 10 parts. At the moment, an average price for metal AM varies from 40 to $100 \mathrm{EUR} / \mathrm{h}$ and iron powder costs are in the range of 30 - 50 EUR.

Cost comparison has shown similar results to production time. For small number of part, the AM technology is cheaper because for the casting technology project start-up costs are higher due to pattern costs. AM has almost a constant price for one part regardless of quantity, especially if the AM machine build size volume allows printing only one part at the same time.

\section{CONCLUSIONS}

The comparison test results have shown that additive manufacturing can be used to produce parts in order to replace the cast parts. All tests for mechanical properties have proven that parts, which are produced using metal additive manufacturing, can provide the same parameters compared to the cast parts and in most of them the results have been even better.

At the moment, the only disadvantages for AM are price and production speed. Price and production time are competitive for small parts and for $1-5 \mathrm{qty}$. because at the moment AM machines are very expensive. The price of one AM machine starts at 250000 EUR till many millions of EUR. In the nearest future, AM machine prices should go down because most of the patents, which protected this technology, ended at the end of 2016 and are not valid anymore. This should also make influence on the metal AM service price, so it is expected to a rapid growth of additive manufacturing in the nearest time.

At the same time, there is already a market niche for AM and it can be used to produce parts for industries where there is no need for series production and part technological possibilities are more important than product price, for example, auto/ motorsport, aviation and prosthetics.

\section{REFERENCES}

1. Gibson I., David W., Rosen D. \& Stucker B. (2006). Additive Manufacturing Technologies: 3D Printing, Rapid Prototyping, and Direct digital manufacturing. New York: Springer.

2. Campbell J. (2002) "Castings" Butterworth-Heinemann.

3. Verdins G. \& Dukulis I., (2008). "Material science" - Riga, LLU.

4. Karnati, S., Axelsen, I., Liou, F. F., \& Newkirk, J. W. (2016). Investigation of tensile properties of bulk and SLM fabricated 304L stainless steel using various gage length specimens. Proceedings of the 27th Annual International Solid Freeform Fabrication Symposium - An Additive Manufacturing Conference (pp. 592-604). Laboratory for Freeform Fabrication and University of Texas at Austin.

5. Gu, D. (2015). Laser additive manufacturing of high-performance materials. Berlin: Springer. 
6. Kamath, C., \& El-dasher, B. (2013). Density of Additively-Manufactured, 316L SS Parts Using Laser Powder-Bed Fusion at Powers Up to 400W. Lawrence Livermore National Laboratory.

\title{
ADITĪVĀS RAŽOŠANAS UN LIEŠANAS TEHNOLOGIJU SALĪDZINĀJUMS - MEHĀNISKO ĪPAŠ̄̇IU, PRODUKTIVITĀTES UN IZMAKSU NOVĒRTĒJUMS
}

\author{
A. Vēvers, A. Kromanis, Ē. Gerinš̌, J. Ozoliņš
}

\section{Kopsavilkums}

\begin{abstract}
Liešanas tehnolog̣ija ir viena no vecākajām ražošanas tehnoloǵijām pasaulē bet pēdējos gados l̦oti strauji attīstās metāla aditīvā ražošana jeb metāla $3 \mathrm{D}$ printēšana. Abas tehnologijas paver iespējas ražot sarežğìtas detaļas ar iekšējiem dobumiem, kā arī, detal̦ām, kuras ir ražotas ar abām tehnoloǵijām, ir līdzīgs virsmas raupjums, kas nozīmē, ka, lai iegūtu precīzus izmērus vai urbumus, detal̦ām būtu nepieciešama virsmu apstrāde. Lai noskaidrotu vai detaļas, kas ražotas ar aditīvo ražošanu varētu aizstāt detaļas, kas iepriekš tikušas ražotas ar liešanas tehnologiju, tika veikti salīdzinošie testi. Autors strādā ķeta liešanas uzņēmumā, tāpēc, lai būtu objektīvs salīdzinājums tika izvēlēts testus veikt ar GJS-400-15 ķeta lējuma marku, kas ir viena no populārākajām augstas stiprības ķeta markām. Ar abām tehnologijām tika izgatavoti paraugi un salīdzinātas to stiepes, cietības un virsmas raupjuma īpašības. Papildus abu tehnologiju salīdzināšanai tika salīdzināti detaļu izgatavošanas laiki un detaļu izgatavošanas izmaksas. Pētījums tika izstrādāts maǵistra darba ietvaros Rīgas Tehniskajā universitātē ražošanas tehnologiiju programmā.
\end{abstract}

28.02.2018. 